\title{
Development of a highly sensitive and selective microplate chemilumi- nescence enzyme immunoassay for the determination of free thyroxine in human serum
}

\author{
Xu Wang ${ }^{1}$, Hui Chen ${ }^{1}$, Jin-Ming Lin ${ }^{1}$, Xitang Ying ${ }^{2}$ \\ 1. The Key Laboratory of Bioorganic Phosphorus Chemistry \& Chemical Biology, Department of Chemistry, Tsinghua Uni- \\ versity, Beijing, 100084, China \\ 2. Beijing Chemclin Biotech Co., Ltd., Beijing Academy of Science and Technology, Haidian, Beijing, 100094, China
}

Correspondence to: Prof. Dr. Jin-Ming Lin, Department of Chemistry, Tsinghua University, Beijing, 100084, China. Tel/Fax: +86-10-62792343. E-mail address: jmlin@mail.tsinghua.edu.cn.

Received: 2007.03.29; Accepted: 2007.04.17; Published: 2007.04.20

A microplate chemiluminescence enzyme immunoassay (CLEIA) with high sensitivity, selectivity and reproducibility was developed for the determination of free thyroxine (FT4) in human serum. A competitive assay has been utilized with horseradish peroxidase (HRP) labeled thyroxine analog in the chemiluminescence (CL) detection. The CL signal produced by the emission of photons from luminol was directly proportional to the amount of analyte. The linear range was 0.45-7.5 $\mathrm{ng} \mathrm{dL}^{-1}$ and the detection limit was $0.09 \mathrm{ng} \mathrm{dL}^{-1}$. Experimental conditions, such as temperature, $\mathrm{pH}$, incubation time, titration level and other relevant variables upon the CL signal have been examined and optimized. A coefficient of variance of less than $16 \%$ was obtained for intra- and inter-assay precision. The present method has been successfully applied to the analysis of FT4 in human serum. The positive and negative coincidence ratios are satisfactory. Good correlations were obtained between the results by the proposed method and radioimmunoassay (RIA), as well as a Bayer ACS-180SE detection system.

Key words: Free thyroxine (FT4); horseradish peroxidase (HRP); chemiluminescence enzyme immunoassay (CLEIA)

\section{Introduction}

Thyroxine $\left(3,5,3^{\prime}, 5^{\prime}\right.$-tetraiodothyronine, $\left.\mathrm{T} 4\right)$ is an important hormone secreted by the thyroid gland. It has a molecular mass of 777 Dalton and is involved in regulating many biological functions, such as oxygen consumption, growth, development and protein synthesis. More than $99.9 \%$ of the T4 in blood is bound to carrier proteins, specially to thyroxine-binding globulin (TBG), and the free fraction of T4 (free T4, FT4) just accounts for $\sim 0.03 \%$ [1]. But the FT4 represents the biologically active form of this compound. It is believed that FT4 could cross cell membranes and interacts with receptors [2], showing metabolically active and clinically relevant effect. Therefore, measurement of FT4 is of value in assessing thyroid function.

Various methods have been employed to the determination of FT4 in serum, such as equilibrium dialysis [3-7], ultrafiltration [8], chromatography on polyacrylamide gel $[9,10]$ or Sephadex [11], radioimmunoassay (RIA) by use of the radioactive isotope 125I [12-14], enzyme immunoassay [15-17], time-resolved fluorescence [18], bioluminescent immunoassay [19], fluoroimmunoassay [20-23], chemiluminescence immunoassay [24, 25], electrochemiluminescence immunoassay [26, 27], and mass spectrometry [28, 29]. These methods have disadvantages. Direct methods are complex and time consum- ing. RIA uses radioactive labels and is harmful to the operators. ELISA has low sensitivity. Immunoassay with chromatography needs a lengthy procedure of column preparation and expensive instrumentation. Electrochemical method requires preparation of working electrodes and complicated operation.

Chemiluminesence enzyme immunoassay (CLEIA) has high sensitivity and specificity. It has been widely used in clinical and biomedical researches due to such advantages as no radioactive waste, relatively simple and inexpensive instrumentation, low detection limit and wide dynamic range. Generally, chemiluminesence detection techniques use horseradish peroxidase (HRP) or alkaline phosphatases (ALP) as label for enzyme immunoassay. These enzymes are labeled to the antibody or antigen molecules. The chemiluminesence substrates undergo a peroxidase-catalyzed oxidation in the presence of a suitable oxidant. After the immunological reaction, the chemiluminesence intensity of the label is detected for the quantitative analysis of antibody or antigen. In this paper, a chemiluminesence enzyme immunoassay for the determination of FT4 is proposed. FT4 presenting in a patient's serum competes with enzyme-T4 analog conjugate for anti-T4 antibodies attached to a solid phase. The amount of enzyme-T4 analog conjugate binding to the solid phase varies inversely with the concentration of FT4 in the serum, constituting the 
estimation of FT4 concentration in the serum. The competitive reaction principle is shown in Figure 1. It is based on the HRP-T4 analog conjugate and the chemiluminesence reaction between the enzyme substrate of luminol and hydrogen peroxide.

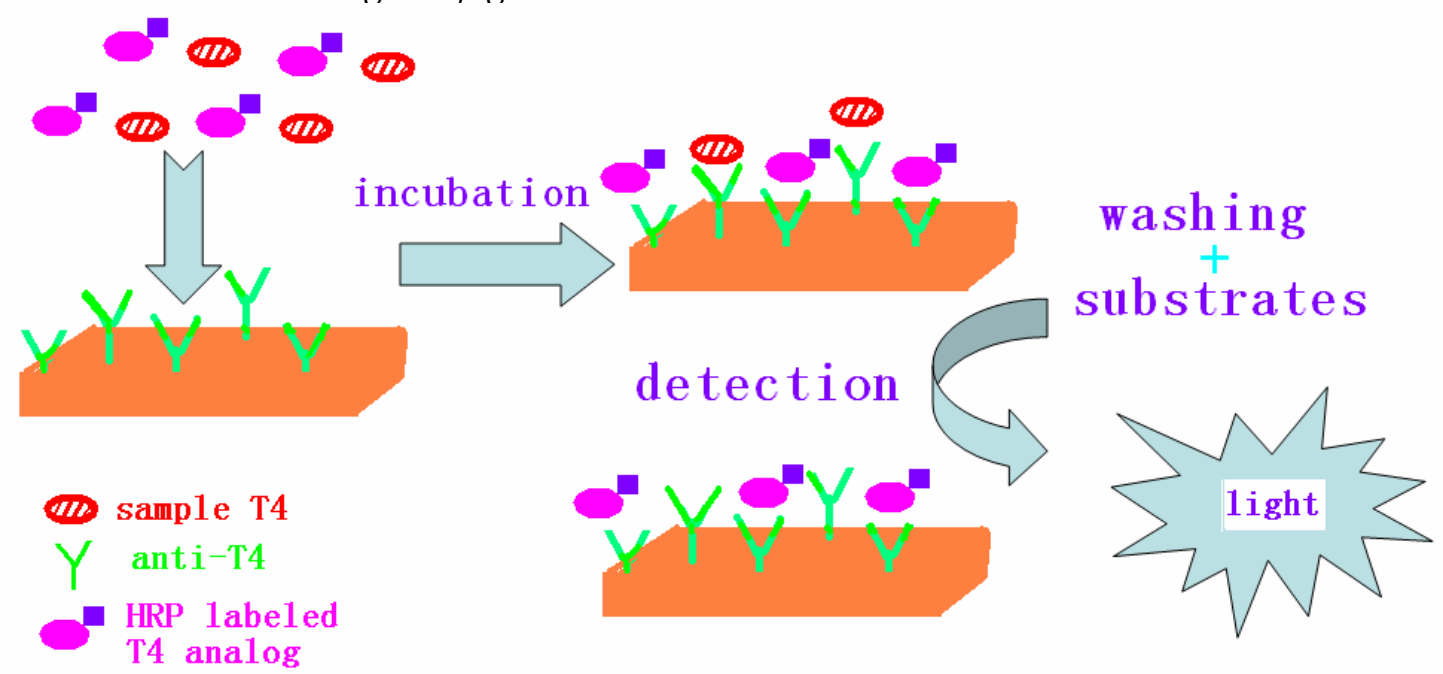

Figure 1. Principle of the chemiluminescence enzyme

\section{Material and Methods}

\section{Chemicals}

T4 standard was obtained from Sigma (St. Louis, USA). Goat anti-T4 polyclonal antibody was purchased from Si Chuan Zheng Long Company (Si Chuan, China). HRP-T $\mathrm{T}_{4}$ analog conjugate was obtained from BAHT Co., Ltd. (Beijing Atom High Tech Co., China). Human sera samples were purchased from Beijing 301 Hospital (Beijing, China). The coating buffer is citrate acid ( $\left.0.06 \mathrm{~mol} \mathrm{~L}^{-1}, \mathrm{pH} 4.8\right)$. The blocking solution was $0.02 \mathrm{~mol} \mathrm{~L}^{-1}$ phosphate buffer containing $1 \%(\mathrm{w} / \mathrm{v})$ BSA and 5\% glucose, $\mathrm{pH}$ 7.4. The washing solution was $0.01 \mathrm{~mol} \mathrm{~L}^{-1}$ Tris- $\mathrm{HCl}$ buffer containing $0.05 \%$ Tween-20, $\mathrm{pH}$ 7.5. Dilution solution for HRP-labeled T4 analog was Tris- $\mathrm{HCl}$ buffer, $\mathrm{pH}$ 6.5. The chemiluminescence substrate were luminol in 0.1 mol L-1 Tris- $\mathrm{HCl}$ of $\mathrm{pH} 8.5$ and $\mathrm{H}_{2} \mathrm{O}_{2}$ in citrate buffer of $\mathrm{pH} 4.5$.

\section{Apparatus}

A chemiluminescence microplate reader (BHP9504 from Hamamatsu Co., China) was used. A microplate mixer (WZ-2A, Beijing Haidian Medical Instrument Factory, Beijing, China) was employed to blend the solutions in microwells. The incubation procedures were carried out using constant temperature incubator (PYX-DHS, Shanghai Medical Instrument Factory, Shanghai, China). An automatic plate washer was used to wash the microplates (DEM-III, Tuopu Analysis Instrument Company, Beijing, China).

\section{Immunoassay procedure}

Immunoassay procedures were presented in Figure 2 [30]. The microplates were coated with $100 \mu \mathrm{L}$ of T4 antibody $\left(2.5 \mu \mathrm{g} \mathrm{mL} \mathrm{mL}^{-1}\right)$ each well in citrate buffer ( $\mathrm{pH}$ 4.8). The plates were allowed to stand sealed at 4 ${ }^{\circ} \mathrm{C}$ overnight. Then, the plates were decanted (tapped and blotted) and post-coated with $300 \mu \mathrm{L}$ blocking buffer for $1 \mathrm{~h}$ at $37^{\circ} \mathrm{C}$. The blocking solution was discarded before assay. In each reaction, $50 \mu \mathrm{L}$ T4 standard solutions or serum samples and $100 \mu \mathrm{L}$ diluted HRP-T4 analog conjugate were added and incubated for $45 \mathrm{~min}$ at $37{ }^{\circ} \mathrm{C}$. After the competitive reaction, the plates were washed five times and $100 \mu \mathrm{L}$ chemiluminescence substrate solution was added, and the emitted photons were measured.

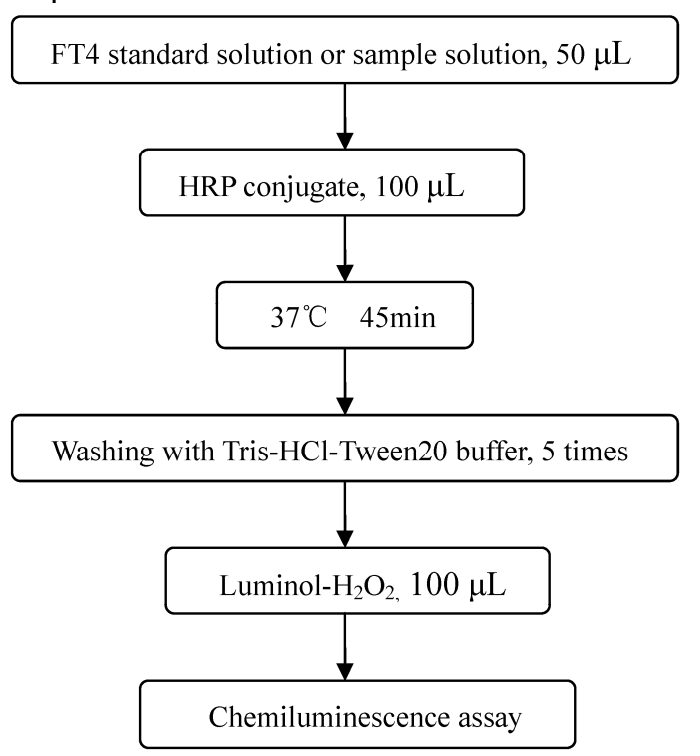

Figure 2. Schematic of chemiluminescence enzyme immunoassay procedures

\section{Data analysis}

Standards and samples were run in double wells, and mean chemiluminescence intensity values were used. Standard curves were obtained by plotting chemiluminescence intensity against the logarithm of analyte concentration. It was fit to the equation of $\operatorname{logit} Y-\log x$, in which the value of $\operatorname{logit} Y$ was calculated 
according to the following formula:

$$
\operatorname{Logit} Y=\ln \frac{B / B_{0}}{1-B / B_{0}}
$$

B- CL intensity of FT4 standard or sample

$\mathrm{B}_{0}-\mathrm{CL}$ intensity of zero standard

\section{Results and Discussion}

\section{Physicochemical parameter optimization}

\section{Effects of temperature and $\mathrm{pH}$}

The equilibrium between bound T4 and FT4 is dependent on the temperature. It has been shown that when the temperature increases from $20{ }^{\circ} \mathrm{C}$ to $37{ }^{\circ} \mathrm{C}$, the concentration of FT4 is doubled [31]. $\mathrm{pH}$ seems to influence the equilibrium between the bound $\mathrm{T} 4$ and the FT4 too [32-34]. The immunoassay reaction was performed at $37{ }^{\circ} \mathrm{C}$ and room temperature, respectively. At $37^{\circ} \mathrm{C}$, the detection limit was lower and the $\mathrm{R}$ (linear correlation coefficient) was higher than those at room temperature. Thus $37{ }^{\circ} \mathrm{C}$ incubation time was used. The effects of $\mathrm{pH}$ on the assay performance on the assay performance parameters, including $R$, RLUmax (maximal relative light unit), $\mathrm{IC}_{50}$ (the $\mathrm{T} 4$ concentration causing 50\% inhibition of RLUmax), RLUmax/IC 50 was also studied (Table 1 ). It showed that $\mathrm{IC}_{50}$ value reached a maximum and the correlation coefficient was better at $\mathrm{pH} 6.5$. Thus $\mathrm{pH} 6.5$ was chosen.

Table 1. Effect of $\mathrm{pH}$ on the immunoassay

\begin{tabular}{|c|c|c|c|}
\hline $\mathrm{pH}$ & 6.5 & 7.5 & 8.5 \\
\hline $\mathrm{R}$ & 0.9984 & 0.9904 & 0.9898 \\
\hline $\mathrm{RLU}_{\max }$ & 40140 & 45759 & 48862 \\
\hline $\mathrm{IC}_{50}$ & 0.66 & 0.54 & 0.52 \\
\hline $\mathrm{RLU}_{\max } / \mathrm{IC}_{50}$ & 60818 & 84738 & 93965 \\
\hline
\end{tabular}

Effect of Tween-20

Surfactants were commonly used in ELISA to reduce nonspecific interaction. The influence of Tween-20 on assay performance was examined and the results were shown in Table 2 . Tweeen-20 could interfere with the active sites of reactant molecules which had an impact on the CL signal [35]. The RLU is so high in the absence of Tween-20 that the sample with low, medium, and high concentration can not be distinguished. In the presence of $0.05 \%$ Tween-20, the three samples could be distinguished well. Therefore, $0.05 \%$ Tween-20 was selected.

\section{Effect of Inhibitors}

Adding analyte analog to the sample could influence the equilibrium between the free and protein-bound fractions of $\mathrm{T} 4$, bringing bad assay reproducibility. Thus inhibitors of sodium salicylate and sodium trichloroacetate were tested. Samples with low, medium, and high concentration were chosen to evaluate the effect of the inhibitors. Compared with sodium trichloroacetate, the correlation coefficient was better and stable, and the low and high sample concentration could be distinguished well in the presence of $0.01 \%$ sodium salicylate, thus $0.01 \%$ sodium salicylate was selected in the subsequent work. The results were shown in Table 3.

Table 2. Effect of Tween-20 on immunoassay RLU and sample determination

\begin{tabular}{|c|c|c|c|}
\hline \multicolumn{2}{|c|}{ performance parameters } & $\begin{array}{c}\text { without } \\
\text { Tween-20 }\end{array}$ & $0.05 \%$ Tween-20 \\
\hline \multirow{2}{*}{ RLU } & $\mathrm{S}_{0}$ & 1107747 & 232260 \\
\hline & $\mathrm{S}_{1}$ & 705427 & 102804 \\
\hline & $\mathrm{S}_{2}$ & 536491 & 56047 \\
\hline & $\mathrm{S}_{3}$ & 305467 & 17510 \\
\hline $\begin{array}{c}\text { sample } \\
\text { concentration } \\
\text { (ng dL-1) }\end{array}$ & $\mathrm{S}_{4}$ & 240786 & 11549 \\
\hline $\mathrm{R}$ & low & $\mathrm{N} / \mathrm{A}$ & 2.73 \\
\hline & medium & $\mathrm{N} / \mathrm{A}$ & 3.78 \\
\hline
\end{tabular}

Table 3. Optimization of inhibitors on the immunoassay

\begin{tabular}{|c|c|c|c|c|c|}
\hline \multirow{2}{*}{\multicolumn{2}{|c|}{ Inhibitors $\left(\mathrm{g} \mathrm{mL}^{-1}\right)$}} & \multirow{3}{*}{$\begin{array}{c}\mathrm{R} \\
0.9956\end{array}$} & \multicolumn{3}{|c|}{ FT4 determined (ng dL-1) } \\
\hline & & & \multirow{2}{*}{$\begin{array}{c}\mathrm{U}_{1} \\
\mathrm{~N} / \mathrm{A}\end{array}$} & \multirow{2}{*}{$\begin{array}{c}\mathrm{U}_{2} \\
0.68\end{array}$} & \multirow{2}{*}{$\begin{array}{c}\mathrm{U}_{3} \\
1.22\end{array}$} \\
\hline $\mathrm{C}_{7} \mathrm{H}_{5} \mathrm{NaO}_{3}$ & $1.0 \times 10^{-3}$ & & & & \\
\hline & $3.0 \times 10^{-4}$ & 0.9989 & $\mathrm{~N} / \mathrm{A}$ & 1.32 & 2.09 \\
\hline & $1.0 \times 10^{-4}$ & 0.9993 & 0.35 & 3.40 & 1.79 \\
\hline & $1.0 \times 10^{-5}$ & 0.9992 & 0.60 & 3.74 & 1.62 \\
\hline & $1.0 \times 10^{-6}$ & 0.9942 & 0.67 & 1.62 & 1.69 \\
\hline \multirow[t]{9}{*}{$\mathrm{CCl}_{3} \mathrm{COONa}$} & $1.0 \times 10^{-2}$ & 0.9596 & 0.62 & 0.55 & 2.27 \\
\hline & $5.0 \times 10^{-3}$ & 0.9905 & 0.44 & 0.95 & 2.50 \\
\hline & $2.50 \times 10^{-3}$ & 0.9762 & 0.91 & 1.80 & 3.22 \\
\hline & $5.0 \times 10^{-4}$ & 0.9605 & 1.10 & 2.40 & 5.15 \\
\hline & $2.0 \times 10^{-4}$ & 0.9641 & 1.13 & 3.16 & 5.00 \\
\hline & $1.0 \times 10^{-4}$ & 0.9732 & 0.99 & 3.35 & 5.60 \\
\hline & $4.0 \times 10^{-5}$ & 0.9927 & 0.86 & 2.50 & 1.23 \\
\hline & $4.0 \times 10^{-6}$ & 0.9972 & 0.95 & 2.43 & 1.31 \\
\hline & $4.0 \times 10^{-7}$ & 0.9991 & 0.96 & 2.75 & 1.49 \\
\hline
\end{tabular}

Titration level of HRP labeled T4 analog

Titer levels of labeled T4 analog were determined. Upon every dilution we monitored the RLU of T4 standard. When the titration was higher than 1:500, the sensitivity was not satisfied. While the titration was lower than 1:2000, the signal was decreased rapidly. The results were shown in Fig. 3. Therefore, titration level of 1:500 was set.

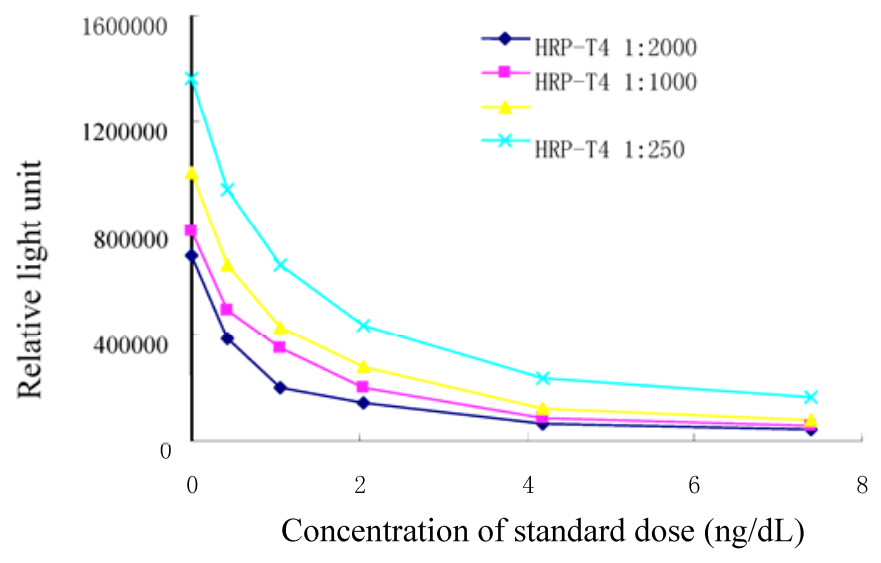

Figure 3. Titration curves of HRP-T4 analog conjugate

\section{Effect of incubation time}

In a competitive ELISA, the interact time between immunoreagents may have a direct effect on the sensitivity of the immunoassay [36]. We varied the incuba- 
tion time from $15,30,45,60,90$ to $120 \mathrm{~min}$, and assessed the variations of $\mathrm{RLU}_{\max }$ and $\mathrm{RLU}_{\max } / \mathrm{IC}_{50}$. Results were shown in Figure 4. The RLU $\mathrm{max}_{\max }$ increased with longer incubation time in the range of $15 \sim 120 \mathrm{~min}$. After $90 \mathrm{~min}$, the $\mathrm{RLU}_{\max }$ did not change evidently. This means the immunoassay reached an equilibrium. $\mathrm{RLU}_{\max } / \mathrm{IC}_{50}$ ratio reached a maximal value at incubation time of $90 \mathrm{~min}$. In order to achieve an appropriate sensitivity suitable for clinical application, an incubation time of $45 \mathrm{~min}$ was set.

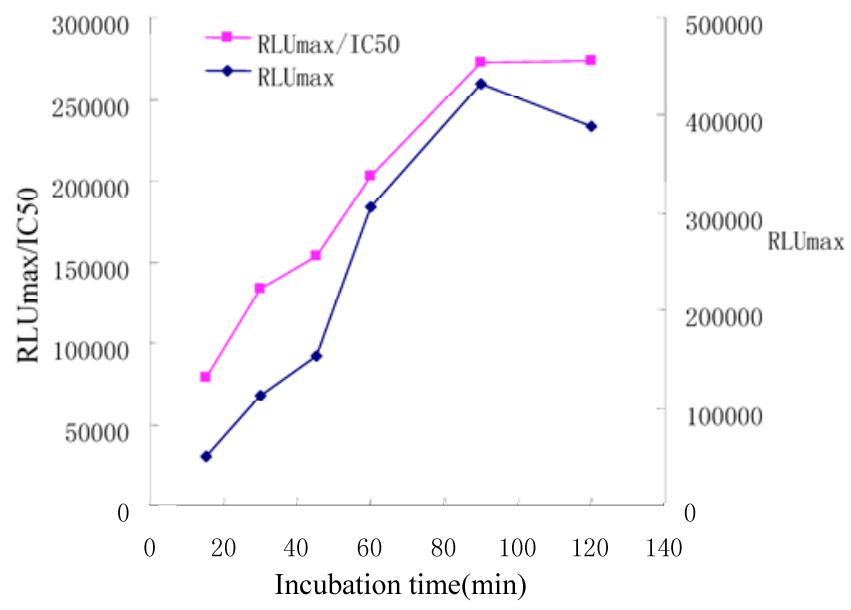

Figure 4. Influence of the length of the competitive step on immunoassay

\section{Calibration and sensitivity}

Under the optimal conditions, the standard curve obtained with the chemiluminescence detection of enzyme activity was presented in Fig. 5. The linear rang was $0.45-7.5 \mathrm{ng} \mathrm{dL}^{-1}$. The sensitivity, defined as the minimal does that can be distinguished from zero, the minimum detected concentration (mean-2S.D. of zero standard, 10 replicates) of FT4 was $0.09 \mathrm{ng} \mathrm{dL}^{-1}$.

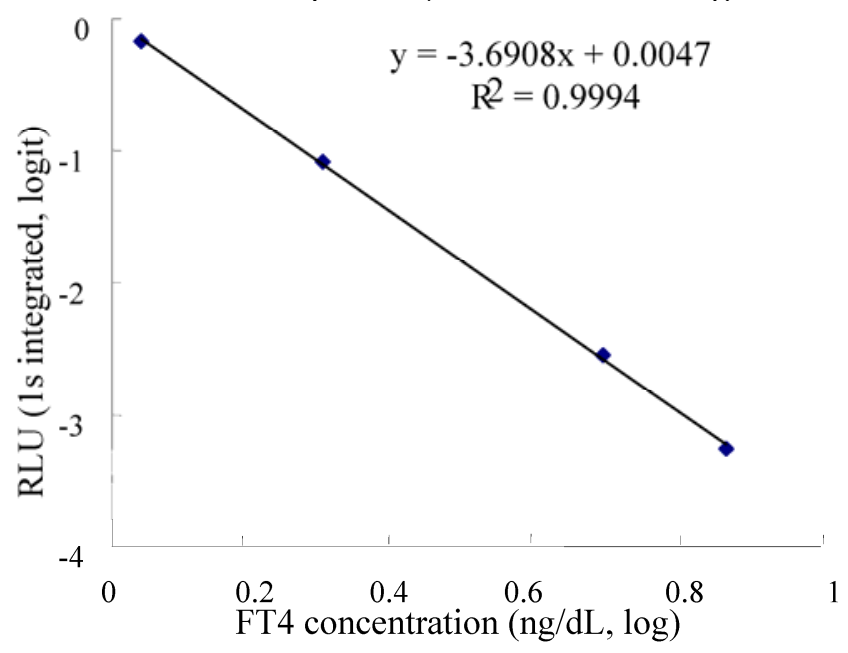

Figure 5. Calibration graph of microplate chemiluminescence enzyme immunoassay for FT4

\section{Precision}

The intra- and inter-assay precisions, calculated by measuring FT4 concentration in three different samples, were performed. Good precisions were ob- tained. The intra- and inter-assay coefficients of variation $(\mathrm{CV})$ varied from 5.3 to $15.6 \%$.

\section{Specificity}

\section{Effect of disrupting compounds}

The specificity of the immunoassay was dependent on the antibody's specificity [37]. The cross-reactivity of the anti-T4 antibody was evaluated using several T4 disrupting compounds. 3,5,3'-triiodothyronine (T3) and 3,3',5'-triiodothyronine (reverse T3, rT3) were the structurally related compounds of T4 (Figure 7) and were tested in this work. The cross-reactivity was calculated by deriving a ratio between does of interfering substance to does of thyroxine needed to displace the same amount of the conjugate. The results were shown in Table 4 . The antibody exhibited cross-reactivity all less than $0.01 \%$. Therefore, effects of T3 and rT3 in serum on FT4 determination could be neglected.

Table 4. Cross-reactivity for FT4 in the present assay

\begin{tabular}{|c|c|c|c|}
\hline $\begin{array}{c}\text { cross-reactive } \\
\text { substance }\end{array}$ & $\begin{array}{c}\text { cross-reactive } \\
\text { substance added } \\
(\text { ng mL-1) }\end{array}$ & $\begin{array}{c}\text { FT4 } \\
\text { deter- } \\
\text { mined } \\
\left(\mathrm{ng} \mathrm{dL}^{-1}\right)\end{array}$ & $\begin{array}{c}\text { Cross-reactivity } \\
(\%)\end{array}$ \\
\hline rT3 & 0.8 & 0.01 & 0.001 \\
\hline FT3 & 25 & 0.26 & 0.010 \\
\hline
\end{tabular}

Interferences

Amount of the interfering substances were added to a serum matrix. The effects of some potential interferences on the determination were shown in Table 5. Sodium citrate and heparin enhanced the CL signal and others inhibited the reaction. The method was simple and sensitive, but these substances need to be removed before it could be used for FT4 determination in blood samples.

\section{Analysis of serum samples}

Expected ranges of values

A study of 70 normal human sera were undertaken to determine expected values. The results were presented in Table 6. It can be seen that the correlation coefficient was $0.9988, \bar{U}$ presenting mean sample values was $1.043 \mathrm{ng} \mathrm{dL}^{-1}$, and standard deviation (SD) was 0.370 . The expected values ( $\overline{\mathrm{U}}+2 \mathrm{SD})$ ranged from $0.303 \mathrm{ng} \mathrm{dL}^{-1}$ to $1.783 \mathrm{ng} \mathrm{dL}^{-1}$.

\section{Clinical sample examination}

Serum samples of normal people and hypothyroid or hyperthyroid patients collected from 301 Hospital were examined. The results were shown in Table 7. The positive and negative samples could be distinguished well and the coincidence ratios were $98 \%$ and $97.5 \%$ for positive and negative samples, respectively.

\section{Correlation with other methods}

FT4 concentrations in the sera were simultaneously determined using the present method, a conventional RIA method and a Bayer ACS-180SE detection system. Good relationships were obtained as shown in Fig. 6a and Fig. 6b, which means this method has great potential in the clinical diagnosis. 
Table 5. Effects of interfering substances on FT4 determination

\begin{tabular}{|c|c|c|c|c|c|c|c|c|}
\hline $\begin{array}{l}\text { Interfering sub- } \\
\text { stances }\end{array}$ & Matrix & $\begin{array}{l}\text { Triglyceride } \\
\left(\text { mmoL L-1 }^{-1}\right)\end{array}$ & $\begin{array}{l}\text { Sodium cit- } \\
\text { rate }\left(\mathrm{g} \mathrm{L}^{-1}\right)\end{array}$ & $\begin{array}{c}\text { Heparin } \\
\left(\mathrm{mg} \mathrm{L}^{-1}\right)\end{array}$ & $\begin{array}{l}\text { Hemoglobin } \\
\left(\mu \text { moL L }^{-1}\right)\end{array}$ & $\begin{array}{l}\text { Sodium } \\
\text { oxalate }(\mathrm{g} \\
\left.\mathrm{L}^{-1}\right)\end{array}$ & $\begin{array}{l}\mathrm{EDTANa}_{2} \\
\left(\mathrm{~g} \mathrm{~L}^{-1}\right)\end{array}$ & $\begin{array}{c}\text { Bilirubin } \\
\left(\mu \mathrm{moL} \mathrm{L}^{-1}\right)\end{array}$ \\
\hline $\begin{array}{l}\text { Conc. of Interfering } \\
\text { Substance }\end{array}$ & 0 & 1.0 & 5.0 & 40 & 0.16 & 1.25 & 1.25 & 0.332 \\
\hline $\begin{array}{l}\text { Total determined } \\
\quad\left(\mathrm{ng} \mathrm{dL}^{-1}\right)\end{array}$ & 0.90 & 0.25 & 1.77 & 0.94 & 0.65 & 0.80 & 0.75 & 0.77 \\
\hline $\begin{array}{c}\text { Interfering substance } \\
\text { determined ( ng } \\
\left.\mathrm{dL}^{-1}\right)\end{array}$ & 0 & -0.65 & 0.87 & 0.04 & -0.25 & -0.10 & -0.15 & -0.13 \\
\hline
\end{tabular}

Table 6. Determination of FT4 in normal serum (ng dL $\left.{ }^{-1}\right)$

\begin{tabular}{|l|l|l|l|l|l|l|l|l|l|l|l|l|l|l|}
\hline $\mathrm{U}_{1}$ & 0.75 & $\mathrm{U}_{11}$ & 1.45 & $\mathrm{U}_{21}$ & 0.74 & $\mathrm{U}_{31}$ & 0.76 & $\mathrm{U}_{41}$ & 1.34 & $\mathrm{U}_{51}$ & 1.05 & $\mathrm{U}_{61}$ & 0.81 \\
\hline $\mathrm{U}_{2}$ & 0.98 & $\mathrm{U}_{12}$ & 2.06 & $\mathrm{U}_{22}$ & 1.12 & $\mathrm{U}_{32}$ & 0.80 & $\mathrm{U}_{42}$ & 0.60 & $\mathrm{U}_{52}$ & 1.01 & $\mathrm{U}_{62}$ & 0.66 \\
\hline $\mathrm{U}_{3}$ & 0.92 & $\mathrm{U}_{13}$ & 1.79 & $\mathrm{U}_{23}$ & 1.77 & $\mathrm{U}_{33}$ & 0.71 & $\mathrm{U}_{43}$ & 1.57 & $\mathrm{U}_{53}$ & 0.70 & $\mathrm{U}_{63}$ & 1.00 \\
\hline $\mathrm{U}_{4}$ & 1.60 & $\mathrm{U}_{14}$ & 1.01 & $\mathrm{U}_{24}$ & 0.81 & $\mathrm{U}_{34}$ & 1.34 & $\mathrm{U}_{44}$ & 1.97 & $\mathrm{U}_{54}$ & 0.66 & $\mathrm{U}_{64}$ & 0.84 \\
\hline $\mathrm{U}_{5}$ & 0.99 & $\mathrm{U}_{15}$ & 0.87 & $\mathrm{U}_{25}$ & 0.83 & $\mathrm{U}_{35}$ & 0.74 & $\mathrm{U}_{45}$ & 1.24 & $\mathrm{U}_{55}$ & 0.76 & $\mathrm{U}_{65}$ & 0.79 \\
\hline $\mathrm{U}_{6}$ & 1.25 & $\mathrm{U}_{16}$ & 1.79 & $\mathrm{U}_{26}$ & 1.34 & $\mathrm{U}_{36}$ & 1.07 & $\mathrm{U}_{46}$ & 0.80 & $\mathrm{U}_{56}$ & 1.47 & $\mathrm{U}_{66}$ & 0.88 & \\
\hline $\mathrm{U}_{7}$ & 0.71 & $\mathrm{U}_{17}$ & 1.17 & $\mathrm{U}_{27}$ & 0.76 & $\mathrm{U}_{37}$ & 1.01 & $\mathrm{U}_{47}$ & 1.29 & $\mathrm{U}_{57}$ & 0.83 & $\mathrm{U}_{67}$ & 0.86 \\
\hline $\mathrm{U}_{8}$ & 0.86 & $\mathrm{U}_{18}$ & 0.84 & $\mathrm{U}_{28}$ & 0.85 & $\mathrm{U}_{38}$ & 0.73 & $\mathrm{U}_{48}$ & 0.80 & $\mathrm{U}_{58}$ & 0.71 & $\mathrm{U}_{68}$ & 0.93 \\
\hline $\mathrm{U}_{9}$ & 0.81 & $\mathrm{U}_{19}$ & 1.17 & $\mathrm{U}_{29}$ & 1.02 & $\mathrm{U}_{39}$ & 0.74 & $\mathrm{U}_{49}$ & 0.85 & $\mathrm{U}_{59}$ & 0.63 & $\mathrm{U}_{69}$ & 0.81 \\
\hline
\end{tabular}

Table 7. Clinical sample examination results

\begin{tabular}{|c|c|c|c|c|c|c|c|}
\hline \multicolumn{2}{|c|}{$\begin{array}{c}\text { Hyperthyroid serum } \\
(\mathrm{n}=47)\end{array}$} & \multicolumn{2}{c|}{ Normal serum $(\mathrm{n}=80)$} & \multicolumn{2}{c|}{$\begin{array}{c}\text { Hypothyroid serum } \\
(\mathrm{n}=51)\end{array}$} & $\begin{array}{c}\text { Positive coinci- } \\
\text { dence ratio }(\%)\end{array}$ & $\begin{array}{c}\text { Negative coincidence ratio } \\
(\%)\end{array}$ \\
\hline $\begin{array}{c}\text { Positive } \\
47\end{array}$ & Negative & Positive & Negative & Positive & Negative & 98.0 & 97.5 \\
\hline
\end{tabular}
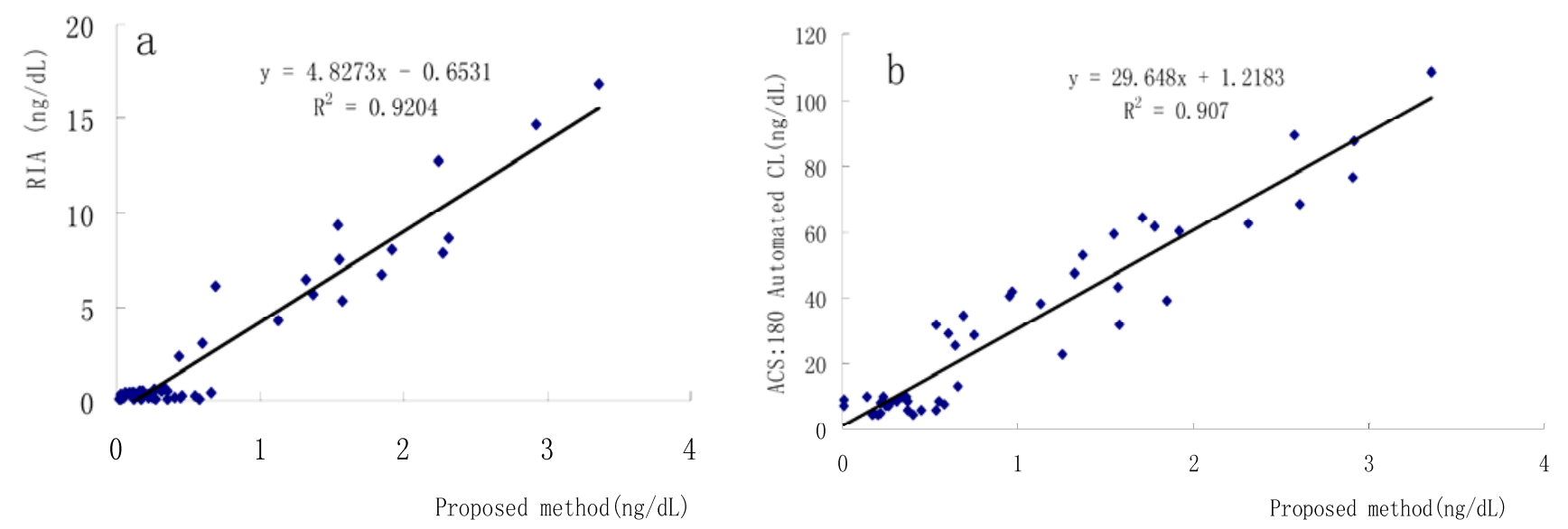

Figure 6. Correlation between the proposed method and other methods. (a) Proposed method and RIA method, (b) proposed method and Bayer ACS-180SE detection system

\section{Conclusions}

A highly sensitive and selective microplate CLEIA demonstrated for the determination of FT4 in serum samples has been developed and optimized. The proposed method comprises anti-T4 antibody coated microplate, HRP-labeled T4 analog and a CL detection system. With the assay, FT4 can be reproducibly detected in human serum at a concentration as low as $0.09 \mathrm{ng} \mathrm{dL}^{-1}$. A stable calibration curve was also established with the linear correlation coefficient of
0.9997. Data from the developed method highlights the acceptable intra-assay (less than 11\%) and inter-assay (less than 16\%) precision. In summary, this assay provides apparent advantages and shows great potential in the clinical diagnosis. 

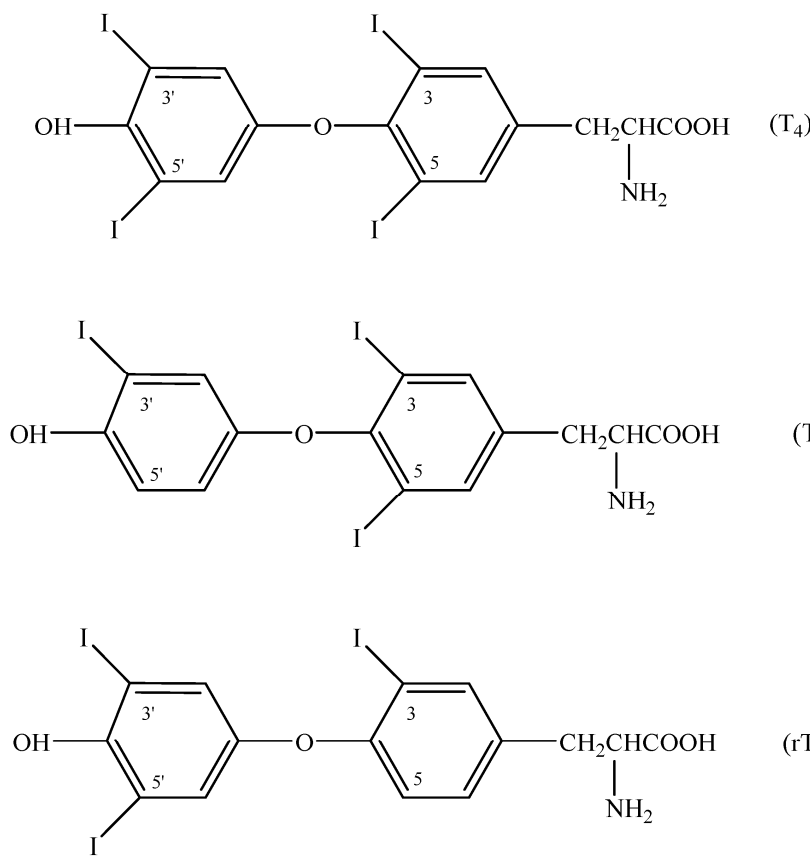

Figure 7. Structures of T4, T3 and rT3

\section{Acknowledgements}

The authors gratefully acknowledge financial support of the National Natural Science Foundation of China (20437020, 20575008) and the Program for Changjiang Scholars and Innovative Research Team in University (IRT0404).

\section{Conflict of interest}

The authors have declared that no conflict of interest exists.

\section{References}

1. Ekins R. Analytic measurements of free thyroxine. Clin Lab Med. 1993; 13: 599-630.

2. Bouknight AL. Thyroid physiology and thyroid function testing. Otolaryngol Clin North Am. 2003; 36: 9-15.

3. Victor SF, Herbert AS. Determination of free thyroxine in serum by low-temperature equilibrium dialysis. Clin Chem. 1970; 16: 185-190.

4. Jerald CN, Wilcox RB, Pandian MR. Dependence of free thyroxine estimates obtained with equilibrium tracer dialysis on the concentration of thyroxine-binding globulin. Clin Chem. 1992; 38: 1294-1300

5. Helenius T, Liewendahi K. Improved dialysis method for free thyroxin in serum compared with five commercial radioimmuno assays in NOnthyroidal Illness and subjects with abnormal concentrations of thyroxin-binding globulin. Clin Chem. 1983; 29 : 816-822.

6. Re'my Sapin, Miche 'le d'Herbomez. Free thyroxine measured by equilibrium dialysis and nine immunoassays in sera with various serum thyroxine-binding capacities. Clin Chem. 2003; 49: 1531-1535.

7. Okabayashi T, Takeda K, Kawada M, Kubo Y, Nakamura S, Chikamori K, Terao N, Hashimoto K. Free thyroxine concentrations in serum measured by equilibrium dialysis in chronic renal failure. Clin Chem. 1996; 42: 1616-1620.

8. Sophianopoulos J, Jerkunica I, Lee CN, Sgoutas D. An improved ultrafiltration method for free thyroxine and triiodothyronine in serum. Clin Chem. 1980; 26: 159-162.

9. McDonald LJ, Robin NI, Siegel L. Free thyroxine in serum as estimated by polyacrylamide gel filtration. Clin Chem. 1978; 24: 652-656.

10. Lewis M. Relationship between TBG concentration and \%FT4 as estimated by dialysis and by polyacrylamide gel filtration. Clin Chem. 1979; 25: 1181-1183.

11. Levinson SS, Rieder SV. Parameters affecting a rapid method in which Sephadex is used to determine the percentage of free Thyroxine in serum. Clin Chem. 1974; 20: 1568-1572.

12. Wilke TJ. Five kits for estimating free thyroxin concentration in serum evaluated, and correlated with other indices to thyroid status. Clin Chem. 1982; 28: 2051-2056.

13. Bayer MF, McDougall IR. Radioimmunoassay of free thyroxinein serum: comparison with clinical finding sand results of conventional thyroid-function tests. Clin Chem. 1980; 26: 1186-1192.

14. Georgiou S, Christofidis I. Radioimmunoassay of free thyroxine (T4) using ${ }^{125}$ I-labeled T4-IgG complex with very large molecular weight. Clin Chim Acta. 1996; 244: 209-220.

15. Ito M, Miyal K, Mizuta KDH, Amino N. Enzyme immunoassay of free thyroxin in serum. Clin Chem. 1984; 30: 1682-1685.

16. Kuns A, Seldenschwarz E, BUrk H, Schauer S, Haug H, Lehmann $P$, Ehrhardt Volker. New one-step enzyme immunoassay for free thyroxin. Clin Chem. 1988; 34: 1830-1833.

17. Weetali HH, Herti W, Ward FB, Hersh LS. EnzymeImmunoassay for free thyroxin. Clin Chem. 1982; 28: 666-671.

18. Khosravi MJ, Papanastasiou-Diamandi A. Hapten-heterologous conjugates evaluated for application to free thyroxine immunoassays. Clin Chem. 1993; 39: 256-262.

19. Frank LA, Petunin AI, Vysotski ES. Bioluminescent immunoassay of thyrotropin and thyroxine using obelin as a label. Anal Biochem. 2004; 325: 240-246.

20. Maria P. Oxytocin decreases plasma levels of thyroid-stimulating hormone and thyroid hormones in rats. Regulatory Peptides. 2002; 108: 83-87.

21. Stevenson HP, Archbold GPR, Johnston P, Young IS, Sheridan B. Misleading serum free thyroxine results during low molecular weight heparin treatment. Clin Chem. 1998; 44: 1002-1007.

22. Reichborn-Kjennerud T, Haug E, Lingjzerde O. Thyroid function in seasonal affective disorder. J Affect Disorders. 1995; 33: 39-45.

23. Zurakowski D, Canzio JD, Majzoub JA. Pediatric reference intervals for serum thyroxine, triiodothyronine, thyrotropin, and free thyroxine. Clin Chem. 1999; 45: 1087-1091.

24. Dhatt GS, Jayasundaram R, Wareth LA, Kerke NN, Jayasundaram K, Darwish EA, Lewis A. Thyrotrophin and free thyroxine trimester-specific reference intervals in a mixed ethnic pregnant population in the United Arab Emirates. Clin Chim Acta. 2006; 370: 147-151.

25. Docter R, Toor HV, Krenning EP, Jong MD, Hennemann G. Free thyroxine assessed with three assays in sera of patients with nonthyroidal illness and of subjects with abnormal concentrations of thyroxine-binding proteins. Clin Chem. 1993; 39: 1668-1674.

26. Navarro MA, Palencia T, Bonnín MR, Rosel P. Daily blank cell procedure in elecsys 2010 improves the reproducibility of thyrotropin, free thyroxine, and triiodothyronine. Clin Chem. 1998; 44:1772-1773.

27. Forest J-C, MEasse J. Evaluation of the analytical performance of the Boehringer Mannheim lecsysT 2010 Immunoanalyzer. Clin Biochem. 1998; 31: 81-88.

28. Soldin SJ, Soukhova N, Janicic N, Jonklaas J, Soldin OP. The measurement of free thyroxine by isotope dilution tandem mass spectrometry. Clin Chim Acta. 2005; 358: 113-118.

29. Stöckl D, Thienpont LMR, Leenheer APD. Towards a reference method for serum free thyroxine based on isotope dilution mass spectrometry. Immunoassay Biol Spec. 2000; 15: 311-317.

30. Zhao LX, Lin J-M. Development of a microplate magnetic 
chemiluminescence enzyme immunoassay (MMCLEIA) for rapid- and high-throughput analysis of 17-estradiol in water samples. J Biotech. 2005; 118: 177-186.

31. Weeke J, Boye N, Örskov H. Ultrafiltration method for direct radioimmunoassay measurement of free thyroxine and free triiodothyronine in serum. Scand J Clin Lab Invest. 1986; 46: 381-389.

32. Holm SS, Hansen SH, Faber J, Staun-Olsen P. Reference methods for the measurement of free thyroid hormones in blood evaluation of potential reference methods for free thyroxine. Clin Biochem. 2004; 37: 85-93.

33. Veer C van der SV, Vermes I, Bonte HA, Hoorn RKJ. Temperature effects on free-thyroxine measurements: analytical and clinical consequences. Clin Chem. 1992; 38: 1327-1331.

34. Ross HA, Benraad TJ. Is free thyroxine accurately measurable at room temperature? Clin Chem. 1992; 38: 880-886.

35. Botchkareva AE, Eremin SA, Montoya A, Manclus JJ, Mickova B, Rauch P, Fini F, Girotti S. Development of chemiluminescent ELISAs to DDT and its metabolites in food and environmental samples. J Immunol Meth. 2003; 283: 45-47.

36. Zhao LX, Lin J-M, Li ZJ. Comparison and development of two different solid phase chemiluminescence ELISA for the determination of albumin in urine. Anal Chim Acta. 2005; 541: 199-207.

37. Zhao LX, Lin J-M, Li ZJ, Ying XT. Development of a highly sensitive, second antibody format chemiluminescence enzyme immunoassay for the determination of $17 \beta$-estradiol in wasterwater. Anal Chim Acta. 2006; 558: 290-295. 